OPEN ACCESS

Edited by:

Youji Wang,

Shanghai Ocean University, China

Reviewed by:

Maria Violetta Brundo,

Università degli Studi di Catania, Italy

Fabio Marino,

Università degli Studi di Messina, Italy

${ }^{*}$ Correspondence:

Francesca Carella

francesca.carella@unina.it

Specialty section:

This article was submitted to

Aquatic Physiology,

a section of the journal

Frontiers in Physiology

Received: 27 March 2018

Accepted: 16 May 2018

Published: 12 June 2018

Citation:

Carella F, Aceto S, Mangoni O, Mollica MP, Cavaliere G, Trinchese G,

Aniello F and De Vico G (2018)

Assessment of the Health Status of Mussels Mytilus galloprovincialis Along the Campania Coastal Areas:

A Multidisciplinary Approach.

Front. Physiol. 9:683.

doi: 10.3389/fphys.2018.00683

\section{Assessment of the Health Status of Mussels Mytilus galloprovincialis Along the Campania Coastal Areas: A Multidisciplinary Approach}

\author{
Francesca Carella*, Serena Aceto, Olga Mangoni, Maria Pina Mollica, Gina Cavaliere, \\ Giovanna Trinchese, Francesco Aniello and Gionata De Vico
}

Department of Biology, University of Naples Federico II, Naples, Italy

The bivalve Mytilus galloprovincialis has a broad geographic distribution, represent an important species for the ecology of coastal waters, also constituting a major aquaculture species. In the present work, molecular and tissue biomarkers were examined in mussel populations ( $M$. galloprovincialis) located in four different areas of the coastal water of the Campania Region. During an annual life cycle, we analyzed the expression patterns of several genes commonly used to estimate cellular stress response and damage, namely p53, p63, HSP70, MT-10, and MT-20, related tissue lesions (pathogens, inflammations, digestive tubules damage), oxidative stress indicators $\left(\mathrm{H}_{2} \mathrm{O}_{2}\right.$, SOD specific activity) and associated environmental data. The computed Principal Component Analysis showed that the areas were discernible based on the environmental data and biomarker results. About animal health status, mussels from Gulf of Pozzuoli and Naples's harbor did show a thinnest epithelial cell of digestive tubules compared to mussels sampled from other sampling sites; moreover, high prevalence of cases of intersex in three of the examinated areas were observed. The presence of a potential zoonotic pathogen (Nocardia crassostreae) was identified, appearing as an important possible emerging disease. We also reported the OIE notifiable protozoa Marteilia refringens in three areas out of four. The likely impact of both observed pathogens on the mussel health and shellfish aquaculture needs to be urgently addressed. Results are discussed considering animal histopathological health parameters and biological effects.

Keywords: biomarkers, environmental stressors, cell damage, mussel, health status, mitochondrial function

\section{INTRODUCTION}

Marine animals lives in polluted coastal waters nearness anthropized areas are more exposed to a multiple toxic substances of domestic and industrial origin. Increasing social apprehension about the environmental quality and vulnerability of biodiversity of the marine coastal areas have been observed in recent years, both on a global and local scale (de Sherbinin et al., 2007; Beaugrand et al., 2015; Ramiìrez et al., 2017). Historically, bivalve mollusc Mytilus galloprovincialis has an important tradition in Italy as both food and income source from natural banks and farming production 
(FAO, 2015). Relatively little is known about mussels health status in the area and the effect of pathogens, source of stress and parasites in this region (Carella et al., 2010, 2013a,b; Trinchella et al., 2013).

Lately, several studies have highlighted the importance of biomarkers integrated approach to describe the health status of animal organisms in order to understand the impact of climate change and human activities (Salihoglu et al., 2013; Hook et al., 2014; Mangoni et al., 2016). Mussels, as all the filter feeders, are exposed to a variety of natural stressors that, along with genetic differences in susceptibility to stress, result in an increased variability of molecular and tissue responses (Marigomez et al., 2013). The use of battery of biomarkers can result, for all these reasons, necessary and useful in environments where complex combinations of environmental factor can cooperate in a site. A variety of contaminant/stressrelated biomarkers have been suggested to be monitored for an integrated assessment of contaminants, as well as their effects in different seas (Lehtonen et al., 2014). These include tissue end-points, represented by histopathological alterations at a bivalve digestive gland, neoplastic and inflammatory lesions, levels of metallothionein gene expression (Knapen et al., 2007; Gagné et al., 2007), superoxide dismutase (SOD) specific activity and mitochondrial function (Abele et al., 2007; Cravo et al., 2009).

The coastline of the Campania Region extends for $450 \mathrm{~km}$ on the Eastern Tyrrhenian Sea margin and forms three main bays, comprehend from North to South, the Gulfs of Gaeta, Naples and Salerno. The region shoreline is densely populated and characterized by the presence of many industrial and harbor activities, commercial discharges as well as includes some protected or pristine areas (Imperato et al., 2003; Altavista et al., 2004; Trifuoggi et al., 2017). Consequently, the coastal water presents distinct trophic characteristics depending on natural and artificial terrestrial inputs (e.g., river runoff, exchanges with adjacent basins), coast orography and coastal circulation. For all the above reasons, in the area it is possible to detect highly distinct eutrophic characteristics, typical of heavily impacted marine waters, as oligotrophic characteristics that are typical of the open sea system of the Tyrrhenian Sea and, more generally, of the entire Mediterranean (Ribera d'Alcalà et al., 2004; Pugnetti et al., 2006; Mangoni et al., 2016).

In order to define the health status of the mussel (M. galloprovincialis) population of the area, we carried out a multidisciplinary study reporting animal tissue lesions (inflammation, digestive tubules damage) expression patterns of the genes p53, p63, HSP70, MT-10, and $M T-20$, oxidative stress indicators $\left(\mathrm{H}_{2} \mathrm{O}_{2}, \mathrm{SOD}\right)$ and environmental data (temperature, inorganic nutrient and chlorophyll-a) during the annual life cycle (Lauenstein, 2012) of M. galloprovincialis. Four different areas in coastal water of the Campania Region were sampled to define the local mussel health status. The aim is to establish possible biological responses associated with potential sources of stress and to determine spatial and seasonal trends. This is the first study of systematic biomonitoring for a whole year in the
Tyrrhenian Sea, using as bio-indicator the indigenous mussels M. galloprovincialis and the seasonal variations of the above parameters.

\section{MATERIALS AND METHODS}

\section{Sampling Sites and Sample Collection}

The study area consisted of four distinct coastal stations along the marine coastal water of the Campania region (southern Italy). The sites comprehended one farm in the southeast part of the sampling area, named Torre del Greco (TG) and three natural banks in the northern part of the coastline: Litorale Domitio (LD), Pozzuoli (PO), and Naples harbor (PN). In particular, the Naples's harbor an important commercial and touristic harbor of the Mediterranean Sea, receives high load of municipal discharges (both untreated and with only primary management) of 1.5 million people. In addition, several industrial activities, port activities (shipbuilding, commercial and tourist transaction) and commercial discharges, takes place in the area (Sprovieri et al., 2007). About the Gulf of Pozzuoli, over the years it has been intensely impacted by different anthropic activities from the brownfield-like the ILVA of Bagnoli, the second largest integrated steel plant in Italy now under remediation by a Government project (Albanese et al., 2010; Arienzo et al., 2017). The collection site was at the level of the Pier of Bagnoli, in the middle of the area. Finally, Litorale Domitio is located in the northwestern coast of the Campania region and is affected by industrial activity (area of production of buffalo Mozzarella), extensive agriculture and other human activities. This district lies between the Patria lake and the River Volturno on an area includes both housing estates and tourist infra-structures (Iterar et al., 2012). The mussels were collected on a floating rope of a temporarily disabled fish cage. Table 1 reports the GPS coordinates for each site and the time course of the samplings. Each sampling consisted of a total of 60 specimens of $M$. galloprovincialis ( $5.2 \pm 0.8 \mathrm{~cm}$ shell length), used for the different analyses. Mussels were transferred alive and kept cool in an insulated sealed container for transit to the laboratory, in order to limit any animal stress and subsequent analysis artifact that may result from the sampling and transport process. Animals were processed for histopathology, gene expression ( $p 53, p 63, H S P 70, M T-10$, and MT-20), oxidative stress $\left(\mathrm{H}_{2} \mathrm{O}_{2}\right.$, SOD), body composition and body energy. Temperature, inorganic nutrient and chlorophylla (Chl-a) data were obtained at the surface to assessing the trophic state of different systems at the time of mussel sampling.

In addition, 60 specimens of M. galloprovincialis were acclimated at the Marine Resources for Research Service (Ma.Re.R) animal rearing facility of the Stazione Zoologica Anton Dohrn $(\mathrm{SZN})$. The animals were placed into open-meshed trays and suspended in a flow-through system with filtered $(0.35 \mu \mathrm{m})$ seawater (temperature: $18^{\circ} \mathrm{C}$, salinity: $33 \% 0,1 \mathrm{~L} /$ animal) and natural photoperiod for 60 days. The water quality parameters (ammonium, nitrate, oxygen, and $\mathrm{pH}$ ) was checked every day. 
TABLE 1 | Collection sites and time course of the samplings.

\begin{tabular}{|c|c|c|c|c|c|c|}
\hline Site name & Abbreviation & Latitude & Longitude & Characteristics & $\begin{array}{l}\text { Collection date } \\
\text { (dd/mm/yyyy) }\end{array}$ & Symbol/season \\
\hline $\begin{array}{l}\text { Litorale Domizio } \\
\text { (Torregaveta) }\end{array}$ & LD & $40^{\circ} 48^{\prime} 31.50^{\prime \prime} \mathrm{N}$ & $14^{\circ} 2^{\prime} 25.56^{\prime \prime} \mathrm{E}$ & Natural population & $\begin{array}{l}01 / 03 / 2012 \\
15 / 05 / 2012 \\
12 / 07 / 2012 \\
11 / 10 / 2012\end{array}$ & $\begin{array}{l}\text { (a) Winter } \\
\text { (b) Spring } \\
\text { (c) Summer } \\
\text { (d) Autumn }\end{array}$ \\
\hline Pozzuoli (Miseno) & $\mathrm{PO}$ & $40^{\circ} 46^{\prime} 50.40^{\prime \prime} \mathrm{N}$ & $14^{\circ} 5^{\prime} 46.96^{\prime \prime} \mathrm{E}$ & Natural population & $\begin{array}{l}01 / 03 / 2012 \\
15 / 05 / 2012 \\
12 / 07 / 2012 \\
11 / 10 / 2012\end{array}$ & $\begin{array}{l}\text { (a) Winter } \\
\text { (b) Spring } \\
\text { (c) Summer } \\
\text { (d) Autumn }\end{array}$ \\
\hline Porto di Napoli & PN & $40^{\circ} 50^{\prime} 35.40^{\prime \prime} \mathrm{N}$ & $14^{\circ} 16^{\prime} 18.40^{\prime \prime} \mathrm{E}$ & Natural population & $\begin{array}{l}12 / 12 / 2011 \\
17 / 05 / 2012 \\
09 / 07 / 2012 \\
11 / 10 / 2012\end{array}$ & $\begin{array}{l}\text { (a) Winter } \\
\text { (b) Spring } \\
\text { (c) Summer } \\
\text { (d) Autumn }\end{array}$ \\
\hline Torre del Greco & TG & $40^{\circ} 47^{\prime} 6.39^{\prime \prime} \mathrm{N}$ & $14^{\circ} 21^{\prime} 38.73^{\prime \prime} \mathrm{E}$ & Farmed population & $\begin{array}{l}07 / 12 / 2011 \\
17 / 05 / 2012 \\
09 / 07 / 2012 \\
17 / 10 / 2010\end{array}$ & $\begin{array}{l}\text { (a) Winter } \\
\text { (b) Spring } \\
\text { (c) Summer } \\
\text { (d) Autumn }\end{array}$ \\
\hline
\end{tabular}

During this period, the mussels were fed with a mixture of Isochrysis galbana, Tetraselmis suecica, and Skeletonema costatum in a continuous algae supply over a period of $24 \mathrm{~h}$ of 150 cells $\mu \mathrm{l}^{-1}$. The animals were used as control for gene expression analysis.

\section{Pathological Evaluation}

Thirty mussels for area for season were processed for routine histopathology. Animal valves were measured. From each animal a transverse section including, mantle, digestive gland, gills and foot were fixed in Davidson's solution for at least $48 \mathrm{~h}$ at room temperature. Another section comprehending heart and kidney was also taken. Subsequently, cuts were embedded in paraffin blocks, sectioned (3-5 $\mu \mathrm{M}$ thick) at rotary microtome, stained with routine haematoxylin and eosin (H\&E) and observed at light microscopy. Additional stains, such as V.O.F. for Marteilia sp. (Gutiérrez, 1977), Masson's Trichrome and Schmorl for lipofuscins and Alcian Blue-Periodic Acid/Schiff's (AB-PAS) for polysaccharides (Mazzi, 1977; Howard and Smith, 1983), were also used. All micrographs were captured using a Nikon DS-Fil video camera mounted on a Nikon 50i microscope, connected to a computer. After staining, the slides were examined at light microscope for histopathological diagnosis. Blind-coded labels were used in order to avoid operator's subjectivity. For each sampling, the prevalence of pathological changes (inflammations, tumors, change of sex), regressive phenomena (digestive tubule atrophy, tissue necrosis and lipofuscin accumulation), pathogens (Prokaryote Nocardia crassostreae, Protozoa Martelia refringens, Fungi Steinhausia mytilovum and Helminths Trematodes) and organism reported by literature as symbionts (Idrozoa Eugymnanthea inquilina, Protozoa Ciliates Ancystrum mytili and Platelmintes Turbellarian Urostoma sp.) was evaluated and singularly considered (Carella et al., 2015a), according to Kim et al. (2006).

Defensive phenomena were recorded and evaluated as specific response to pathogens or as unspecific reactions. For each population sample, prevalence of inflammatory lesions was documented and morphologically classified as percentage of Infiltrates, Nodules and Capsules (De Vico and Carella, 2012). Moreover, in the observed samples, a semi-quantitative measure of haemic reaction was also assessed. In particular, each mussel specimen was scored using arbitrary scales for intensity of inflammatory lesions, by visual examination of a single histological section for each case at 40X of magnification. Scales ranged from 1 (25\% of inflammation extended to digestive system) to 4 (heavy inflammatory lesions widespread $>90 \%$ of the digestive system), with the scores 1 and 2 as intermediate levels (Carella et al., 2015b).

For the regressive changes, a semi-quantitative evaluation of the percentage of atrophic digestive tubules (Epithelial Thickness-ET) in the whole tissue section was scored as reported by Kim et al. (2006).

\section{Gene Expression Analysis}

Total RNA was extracted from digestive gland tissue (50 mg) of six specimens stored in RNA Later (Ambion Inc., Austin, TX, United States) at $-20^{\circ} \mathrm{C}$ from each sampling site using TRIzol reagent (Ambion Inc., Austin, TX, United States) followed by DNase treatment (Carella et al., 2013a). In addition, the digestive gland of two individuals of $M$. galloprovincialis from each sampling site acclimated as described above was used as control tissue. Total RNA was quantified using the spectrophotometer NanoDrop 2000c (ThermoScientific) and its integrity was checked using the Bioanalyzer (Agilent Technologies). One microgram of each RNA per sampling was pooled, resulting in two pools of total RNA from three individuals per sampling. For each pool, three micrograms of total RNA were reverse transcribed using the reverse transcriptase Superscript III (Invitrogen, San Diego, CA, United States) and random hexamers following the conditions previously described (Carella et al., 2013a). Real Time PCR experiments were conducted to measure the relative expression level of the genes $M T-10, M T-20, p 53$, p63, and HSP70 using the 18S rRNA as endogenous control 
gene, following the conditions previously described (Aceto et al., 2011). The reactions were conducted in technical triplicates. Primer pairs specific for each gene are listed in Table 2. Primers to amplify $M T-10, M T-20$ and $18 \mathrm{~S}$ were previously reported in Aceto et al. (2011); primers to amplify HSP70 and p53 were designed using the Primer Express software v.3.0 (Applied Biosystems), based on the sequence of the HSP70 (accession number AY861684), p53 (KC545827) and p63 (MF997537) mRNA of M. galloprovincialis present in GenBank. The relative expression levels of the target genes were calculated applying the comparative $\mathrm{Ct}(\Delta \Delta \mathrm{Ct})$ method, using the digestive gland cDNA of the acclimated animals as the reference sample and the $18 \mathrm{~S}$ as the endogenous control. Differences in the relative expression levels among the sampled populations were assessed by ANOVA analysis followed by a Games-Howell post hoc test.

\section{Lipid Extraction and Body Composition}

The total lipid content was determined by using the method of Folch et al. (1957). To obtain the lipid fraction, the tissue was collected from 5 different individuals (with 3 replicates), washed with filtered seawater and finely minced. Lastly $0.5 \mathrm{~g}$ of tissue was homogenized in $1.1 \% \mathrm{NaCl}$ and lipids were extracted in chloroform:methanol solution $(2: 1, \mathrm{v} / \mathrm{v})$.

Energy, water, fat and protein content in animal carcasses were measured according to Iossa et al. (2002).

\section{Preparation of the Mitochondrial Fraction}

After mussels dissection, mantle and gill tissues were removed, pooled and washed in ice-cold medium A (0.25 M sucrose, $5 \mathrm{mM}$ Tris-EDTA, pH 7.4). The tissues were dried, weighted and subsequently homogenized in medium B $[0.25 \mathrm{mM}$ sucrose, $0.5 \mathrm{~g} / \mathrm{L}$ bovine serum albumin (BSA), Tris $24 \mathrm{mM}$, $\mathrm{pH}$ 7.6], in the proportion $11 \mathrm{~mL}$ medium $\mathrm{B} / \mathrm{g}$ of tissue, by Ultraturrax T25 (IKA-Labortechnik) at 14,000 rpm for 1 min. The mitochondrial fraction from gills and mantle was obtained by stepwise centrifugation. The homogenate was centrifuged at $1500 \mathrm{~g}$ for $10 \mathrm{~min}$, the supernatant was filtered through sterile gauze layers and further centrifuged at $9000 \mathrm{~g}$ for $12 \mathrm{~min}$. The resulting precipitate was resuspended in medium B and further centrifuged at the same speed for $12 \mathrm{~min}$ to obtain the mitochondrial pellet which was

TABLE 2 | Sequence $\left(5^{\prime}-3^{\prime}\right)$ of the primer pairs used to perform the Real Time PCR experiments.

\begin{tabular}{lll}
\hline Gene & Forward & Reverse \\
\hline MT-10 & GGGCGCCGACTGTAAATGTTC & CACGTTGAAGGCCCTGTACACC \\
MT-20 & TGTGAAAGTGGCTGCGGA & GTACAGCCACATCCACACGC \\
p53 & TGGCTGTCGATGATACTGG & TTATTCCTGGTCGATGTTG \\
p63 & CCAATGAGCCAGGAAACATT & GGTTCATCCTCAGCTCACT \\
Hsp70 & GGACAAGCAACAAAGGATGC & CCACCACCCAAGTCAAAGAT \\
$18 S$ & TCGATGGTACGTGATATGCC & CGTTCTCATGCTCCCTCTC \\
\hline
\end{tabular}

Primers for MT-10 and MT-20 are from Aceto et al. (2011). resuspended in a small quantity of medium $B$, to obtain a protein concentration of $10-12 \mathrm{mg} / \mathrm{mL}$ determined by Hartree method (Hartree, 1972). All steps were carried out at $0-4^{\circ} \mathrm{C}$.

\section{Evaluation of Mitochondrial Respiratory Activities}

Mitochondrial oxygen consumption was measured polarographically with a Clark-type electrode in a 3-ml glass cells, at a temperature of $20^{\circ} \mathrm{C}$ (Estabrook, 1967). Isolated mitochondria $(1 \mathrm{mg} / \mathrm{ml})$ were incubated in a medium containing $0.2 \mathrm{M} \mathrm{KCl}, 5 \mu \mathrm{M}$ cytochrome c, $5 \mathrm{mg} / \mathrm{mL}$ fatty acid-free BSA, $20 \mathrm{mM}$ Tris- $\mathrm{HCl}, \mathrm{pH} 7.2 ; 6 \mathrm{mM} \mathrm{KH} 2 \mathrm{PO}$. The rate of oxygen consumption was assessed in the presence of $3 \mathrm{mM}$ of succinate for complex II and $0.6 \mathrm{mM}$ of ADP. The respiratory control ratio (RCR), calculated as the ratio between State 3 and 4 activities, were determined as defined by Chance and Williams (1955). Polarographic assays of mitochondrial preparations from distinct animal pools were carried out at least in triplicate, according to Pagliarani et al. (1994).

\section{Determination of Mitochondrial SOD Activity and $\mathrm{H}_{2} \mathrm{O}_{2}$ Release}

Superoxide dismutase specific activity was measured spectrophotometrically $(550 \mathrm{~nm})$ at $25^{\circ} \mathrm{C}$, by monitoring the decrease in the reduction rate of cytochrome $\mathrm{c}$ by superoxide radicals, generated by the xanthine-xanthine oxidase system. Mitochondria were incubated in a medium containing $0.1 \mathrm{mM}$ EDTA, 2 mM KCN, 50 mM KH2PO4, pH 7.8, 20 mM cytochrome c, $5 \mathrm{mM}$ xanthyne, and $0.01 \mathrm{U}$ of xanthyne oxidase. One unit of SOD activity is defined as the concentration of enzyme that inhibits cytochrome c reduction by $50 \%$ in the presence of xanthine + xanthine oxidase (Flohé and Otting, 1984).

Rate of mitochondrial $\mathrm{H}_{2} \mathrm{O}_{2}$ release was assayed by following the linear increase in fluorescence (excitation at $320 \mathrm{~nm}$, emission at $400 \mathrm{~nm}$ ) due to the oxidation of homovanillic acid in the presence of horseradish peroxidase by using Jasco fluorometer equipped with a thermostatically controlled cell-holder $\left(30^{\circ} \mathrm{C}\right)$. Mitochondrial proteins $(0,4 \mathrm{mg})$ and succinate $(0,6 \mathrm{M})$ were incubated in the solution used for the determination of $\mathrm{O} 2$ consumption. Different known concentrations of $\mathrm{H}_{2} \mathrm{O}_{2}$ (from $0.5 \mu \mathrm{M}$ to $8 \mu \mathrm{M}$ ) were progressively added to establish the standard concentration curve (Barja, 1998).

\section{Physical and Chemical Data}

Temperature data, at the time of mussel collection, was obtained from a Sea Bird Electronic, SBE 19 Plus CTD probe. Surface water samples were collected at the surface from the Niskin bottle at the end of the trophic state of different systems. After careful mixing, subsamples were distributed to determine inorganic nutrient and phytoplankton biomass (in terms of chlorophyll-a).

To determine nutrient concentrations (NO3-, NO2-, NH4+, $\mathrm{Si}(\mathrm{OH}) 4$, PO43-) samples were collected in $20 \mathrm{~mL}$ lowdensity polyethylene containers and stored at $20^{\circ} \mathrm{C}$ until further analysis. The analyses were performed using a Flow Sys System 


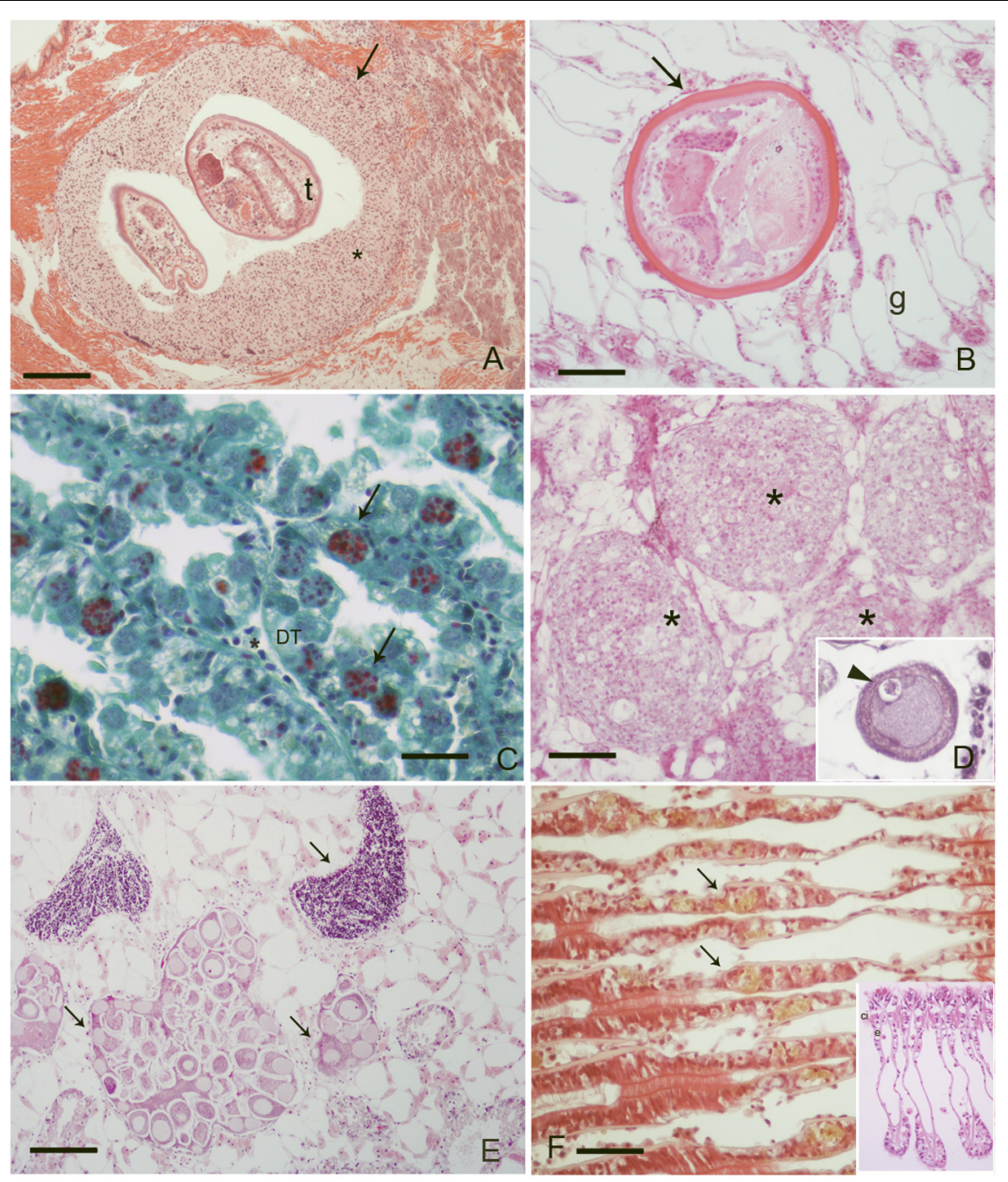

FIGURE 1 | Pathogens and diseases observed during the study: (A) Inflammatory capsule $\left(^{*}\right)$ surrounding trematodes (t) parasites at mussel foot level, (Scale bar: $100 \mu \mathrm{M})$; (B) unknown metacercaria at gill level (g) with no immune response from the host (Scale bar: $50 \mu \mathrm{M}$ ); (C) M. refringens (arrows) in the digestive tubules (DT) of mussels, (Scale bar: $10 \mu \mathrm{M})$. V.O.F. Stain; (D) nodulation at gondal level in infection by S. mytilovum (insert, arrowhead) (Scale bar: $50 \mu \mathrm{M}) ;(\mathbf{E})$ DSD (Disorders of Sex Development) at gonadal level: note the presence of both male and female follicles in the same individual (Scale bar: $100 \mu \mathrm{M}$ ); (F) intraepithelial haemocytes (arrows) at gill level containing lipofuscin (arrows), (Scale bar: $50 \mu \mathrm{M}$ ) insert: normal gills; e, epithelia; ci, cilia; *, haemocytes.

autoanalyzer, following the procedure described by Hansen and Grasshoff (1983). $500 \mathrm{~mL}$ of seawater were filtered into $25 \mathrm{~mm} \mathrm{GF/F} \mathrm{Whatman} \mathrm{filters} \mathrm{for} \mathrm{phytoplankton} \mathrm{biomass.}$ Filters were stored in liquid nitrogen until further analysis. The analyses of chlorophyll-a (Chl-a) and phaeopigments (Phaeo) were carried out according to Jeffrey and Humphrey (1975), with a spectrofluorometer (Spex), which was checked daily with a Chl-a standard solution (from Anacystis nidulans; Sigma).

\section{Statistical Analysis}

The statistical analysis of the data was performed using SPSS 21 (SPSS Inc., Chicago, IL, United States). Normality of data (Kolmogorov-Smirnov's test) were tested before statistical analysis.

Principal component analysis (PCA) was performed to group the data set into few variables that could explain most of the variance associated to the samples. Pearson correlation coefficients were calculated between gene expression values, biomarker responses, and environmental data.

\section{RESULTS}

Results obtained from all the analyses of the mussels (M. galloprovincialis) sampled in the 4 localities along the Campanian coast are given in Figures 1-9 and Tables 1-5.

\section{Pathological Conditions Recorded}

Specimens from the different areas showed diverse types of lesions, mostly represented by inflammations of various degree and type, and atrophy of epithelial tubules of digestive gland. In particular, inflammation such as haemocytic infiltration, 


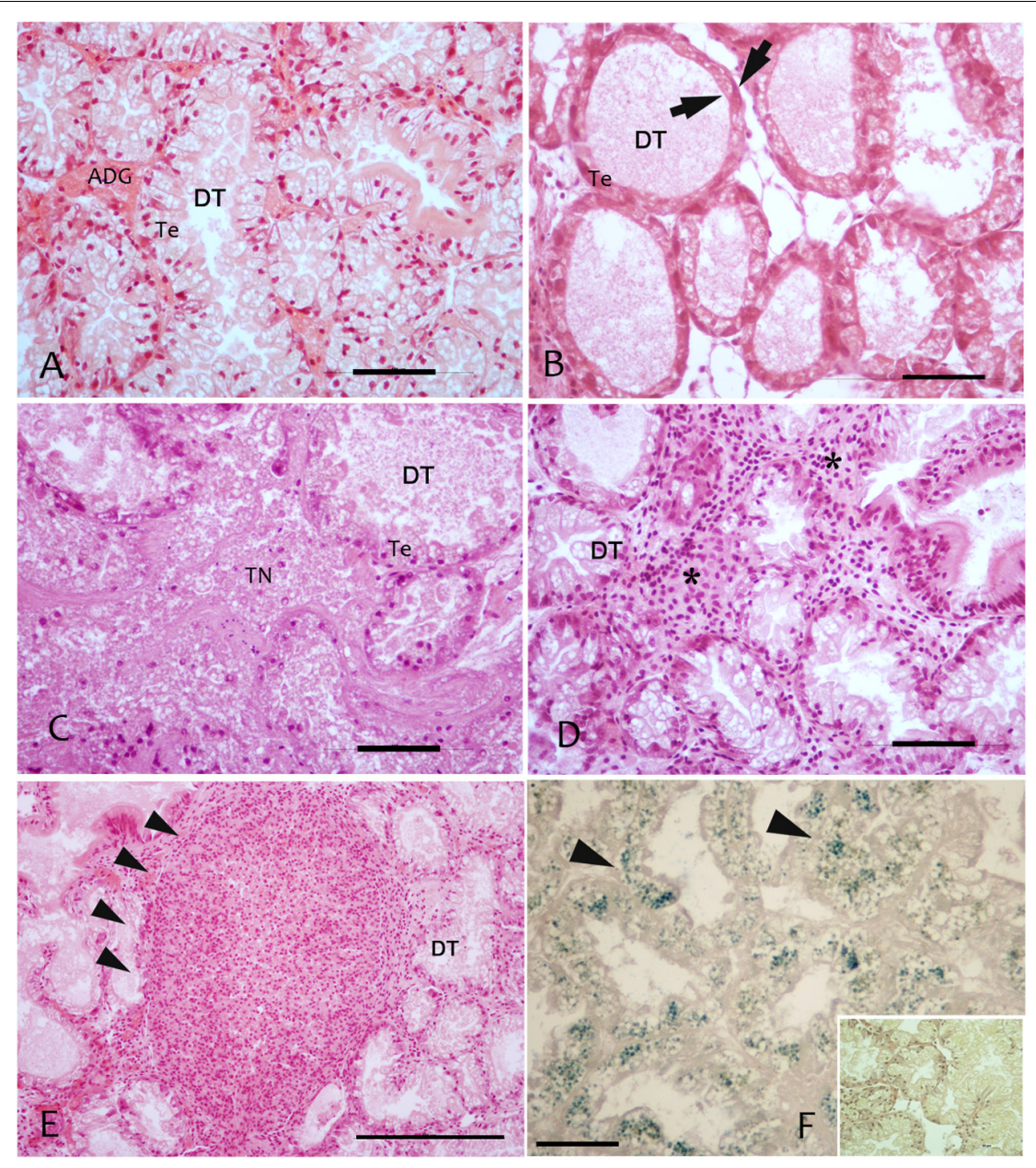

FIGURE 2 | Regressive and inflammatory lesion at digestive gland level observed in the studied areas in sampled mussels M. galloprovincialis; (A) Digestive tubules (DT), showing a normal adsorbing epithelia (TE); (B) Atrophic digestive tubules (DT) with epithelia thinning (arrows) in PN; (C) Colliquative Necrosis (TN) of digestive tubules in LD; (D) Infiltrative inflammation (*) among digestive tubules; (E) Inflammatory nodules (arrowheads) occupying most of the digestive tissue; (F) Lipofuscin accumulation in digestive cells of DT underlined by Schmorl staining and visible as yellow pigment in H\&E stain (insert). Scale bar: $50 \mu \mathrm{M}$. TN, tissue Necrosis; Te, tubule epithelium; DT, digestive tubules; *, haemocytes.

nodules and capsules have been largely recorded in the digestive system of mussels, showing a temporal stratification, occasionally associated to protozoan parasites like Marteilia refringens, Fungi Steinhausia mytilovum and other pathogens (Figures 1-4 and Table 3). Bacterial infections from Nocardia crassostreae was observed in the digestive gland of samples from PN area, with colonies presence always accompanied by a strong haemocytic incapsulation.

Regarding the digestive tissues, the histological integrity of the digestive gland tubules was reduced in mussels from most of the studied localities, mostly represented in all the period in PO and PN. In many cases the digestive tissue was occupied by a disorganized interstitial connective tissue with infiltrating haemocytes or occupied by granulocytomas. Digestive ducts could be dilated in some case containing lipofuscin and presented an enlarged lumen and thinnest epithelium (Figures 2-3). Necrotic tissue circumscribing adductor muscle was also recorded in $\mathrm{LD}(13 \%)$ and TG (10\%) during winter season and macroscopically visible during sampling.

Interestingly, cases of Disorders of Sex Development (DSD) represented by intersex, were recorded during Spring and Summer in three of the examined areas at higher percentage (10-15\%). Co-existence of both female and males follicles was observed, with mature oocytes and spermatozoa (Figure 1E).

\section{Gene Expression Analysis}

Figure 5 shows the relative expression levels of the target genes MT-10, MT-20, p53, p63, and HSP70 of M. galloprovincialis in the different collection sites. Measures are reported as mean values \pm standard error of the mean (SEM). All but one the genes (MT-20) show expression levels generally higher than the acclimated controls (not reported in the graphs, whose expression level is 1) during the time course of the samplings. All the examined genes show a peak of expression during the summer, and in some cases 


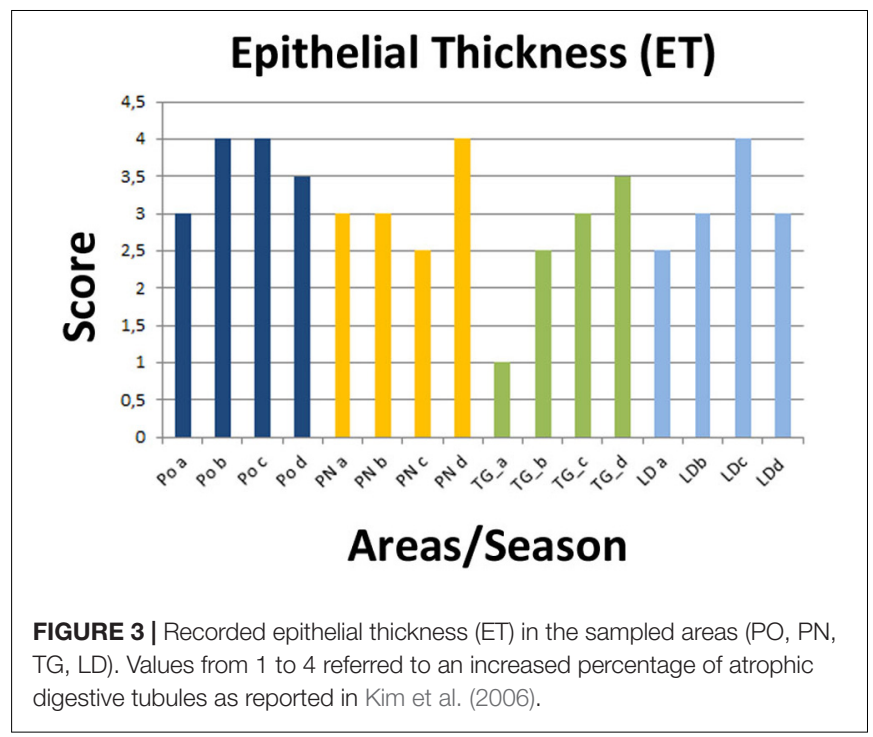

(e.g., MT-10 for the PN sampling) the autumn. The PN and TG sites show the highest mean values of the biomarkers examined.

\section{Variations in Body Composition}

Specimens from the different areas showed changes in body composition mostly linked to the sampling season. The most significant differences were observed during summer, when the organisms of the four different areas showed the lowest body water content associated with an increase in lipid, protein and energy content. A decrease of these parameters was disclosed during autumn and winter as reported in Figure 6.

\section{Mitochondrial Respiration Rates and Oxidative Stress}

The influences of the seasonal variations on mitochondrial oxidative capacity was evaluated using FAD (succinate)- and NAD (glutamate)-linked substrates. The mitochondrial oxidative rates measured using succinate as substrate revealed that the specimens of TG and LD site displayed the lowest state 3 and state 4 values during autumn and winter, and a significant increase was observed during spring and summer. The organisms of PO area showed an increase in state 4 respiration rate during spring, further enhanced in summer season. No difference was noticed in the state 3 evaluation during the time course of samplings. Interestingly, no differences in mitochondrial respiration rates were observed in the specimens of PN site during the different times of the year and the values were significantly lower compared to the other sampling sites.

The mitochondrial respiration rates measured using glutamate/malate as substrates revealed that the specimens of TG site displayed a significantly higher state 3 and state 4 values during summer period as compared to the other seasonal sampling. The LD specimens showed an increase in state 4 respiration rate during spring and summer associated with the higher state 3 values in spring season as compared to the other periods. The lowest state 3 was found during autumn. The organisms of PO area showed no difference in the state 4 evaluation during the time course of samplings, whereas the
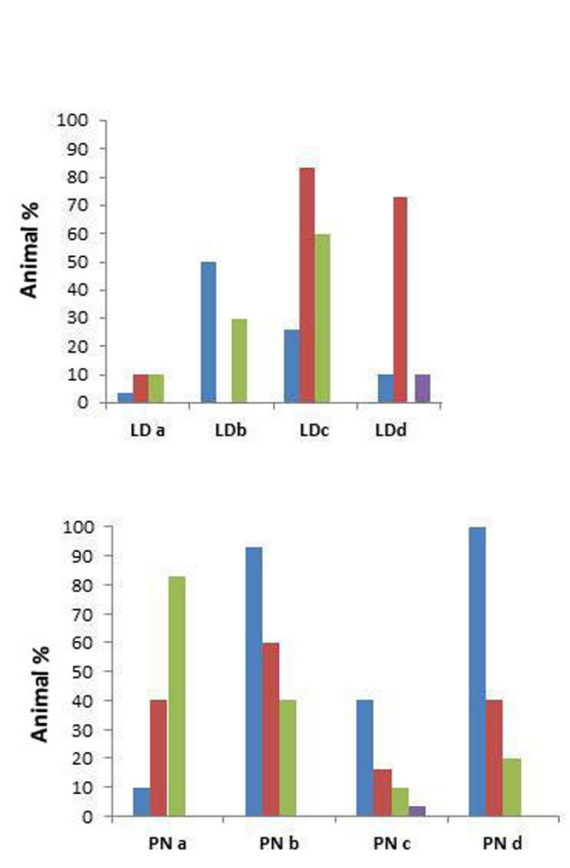
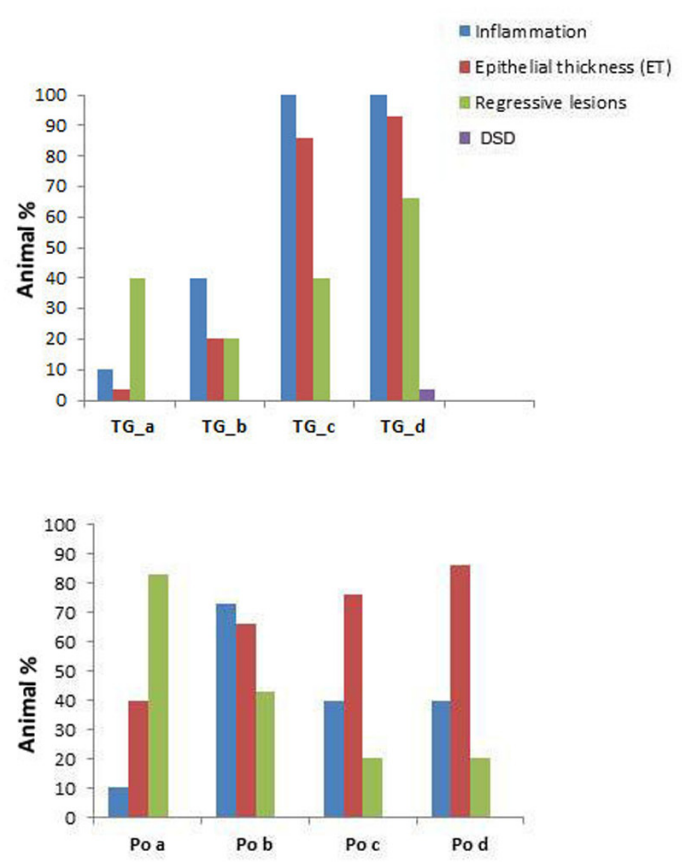

FIGURE 4 | Prevalence of the pathological conditions (inflammation, epithelial thickness-ET, Regressive lesions and Disorsers of Sex Development - DSD) observed in the different tissues in M. galloprovincialis collected at the different sites and periods. 


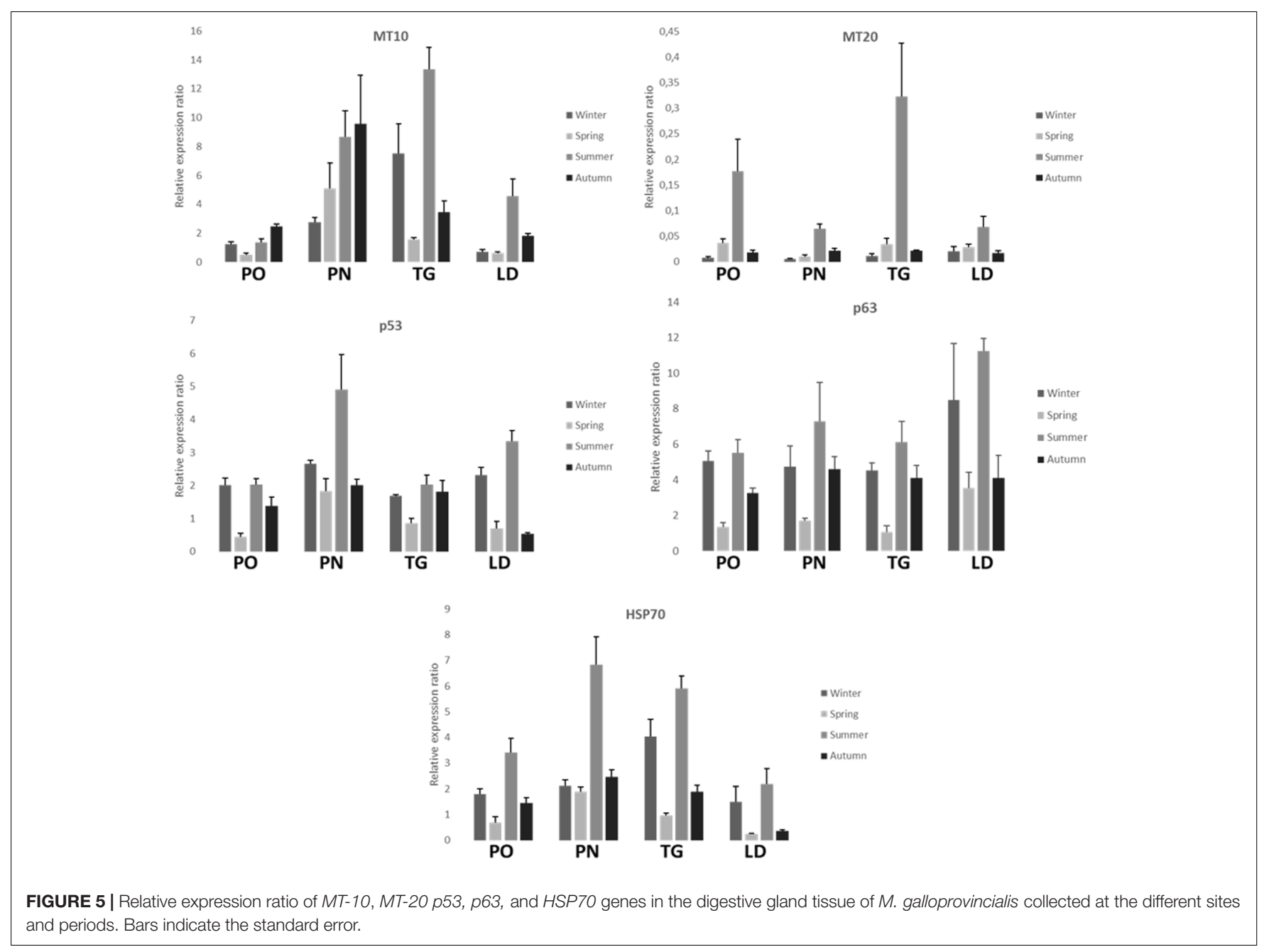

highest state 3 rate was found in summer season. The organisms of PN site showed an increase in state 4 only during the spring period associated with highest values of state 3 in spring and summer seasons (Figure 7).

\section{Oxidative Stress}

The organisms of PO and TG areas revealed a significant increase in $\mathrm{H}_{2} \mathrm{O}_{2}$ yield during summer season as compared to the other periods, the lowest production was found during autumn. The $\mathrm{LD}$ and $\mathrm{PN}$ specimens showed the highest $\mathrm{H}_{2} \mathrm{O}_{2}$ yield during spring season, whereas a progressive reduction were disclosed in the other times of the year (summer $>$ winter $>$ autumn).

The specimens of TG site showed the lowest SOD activity during autumn, an increase was noticed in winter and summer and the highest activity was revealed during the spring period. The SOD activity in the LD specimens results significantly reduced during autumn as compared to the other seasons. In the organisms of PO area, this enzymatic activity was reduced during autumn and increased in the other periods of the year, the highest SOD activity was found in spring. In the $\mathrm{PN}$ area a higher SOD activity was found in summer season as compared to the other sampling, the lowest activity was measured during the winter (Figure 8).

\section{Environmental Data}

Dissolved inorganic nitrogen (DIN $\left[\mathrm{NO}_{3}{ }^{-}+\mathrm{NO}_{2}{ }^{-}+\mathrm{NH}_{4}{ }^{+}\right]$), $\mathrm{PO}_{4}{ }^{3-}$ and $\mathrm{Si}(\mathrm{OH})_{4}$ concentrations were high in the investigated areas (Table 4). At station $\mathrm{PN}$, the highest concentrations of DIN and $\mathrm{PO}_{4}$ are detected. A marked difference is also evident among the samples collected on the site of TG and LD compared to the site of $\mathrm{PO}$. On the overall, the DIN/P ratio (calculated from the slope of DIN plotted against $\mathrm{PO}_{4}{ }^{3-}$ ) shows an altered ratio in the sites. The DIN/P ratio has exceeded 16 during all seasons in PN, PG stations; on the contrary, in LD and PO stations (except in winter) the DIN/P ratio is much lower. High concentration of silicates was found in TG and PN stations.

Chlorophyll-a (Chl-a) are relatively high and reflected the accumulation of the phytoplankton biomass in the sampling sites (Table 4). The highest values of Chl-a were recorded during summer in the PN and TG stations, with values of 16.030 and $10.470 \mu \mathrm{g} \mathrm{L}^{-1}$, respectively (Table 4), while in the PO station the mean value is $0.765 \mu \mathrm{g} \mathrm{L}^{-1}$. The presence of degraded pigments 

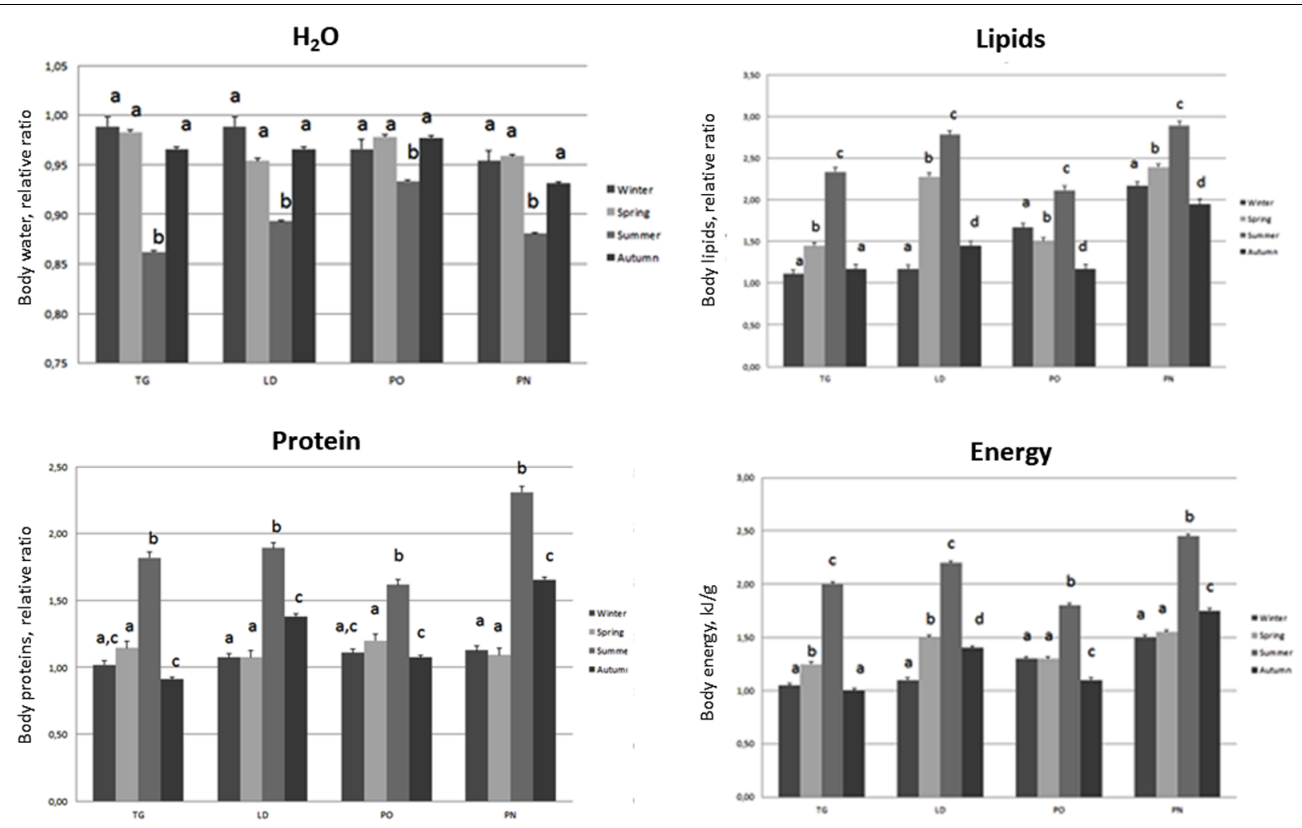

FIGURE 6 | Body composition (Water, Lipid, Protein, Energy) of M. galloprovincialis collected at the different sites and periods. Different superscripted letters indicate statistically significant differences $(P<0.05)$.
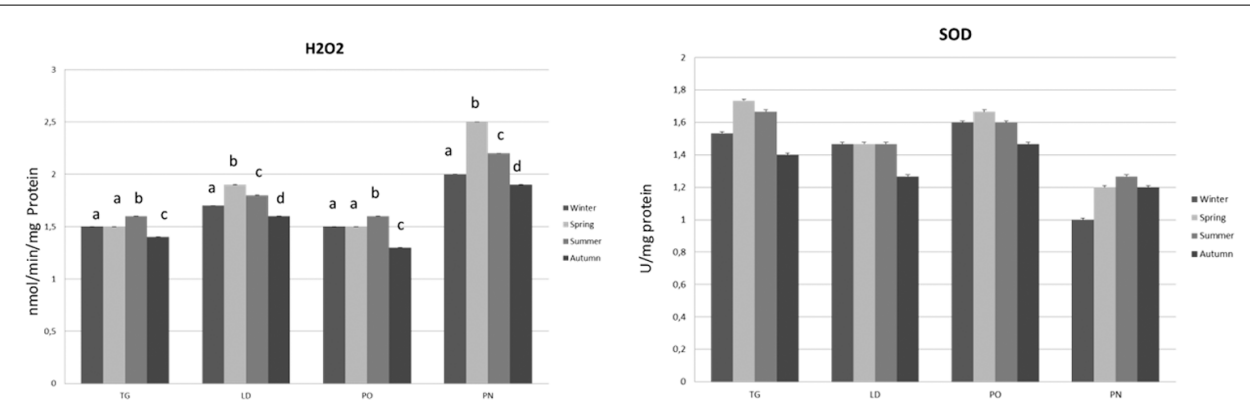

FIGURE 7 | Hydrogen peroxide $\left(\mathrm{H}_{2} \mathrm{O}_{2}\right)$ and SOD (Superoxide Dismutase) of $M$. galloprovincialis collected at the different sites and periods. Different superscripted letters indicate statistically significant differences $(P<0.05)$.

(high values of Pheo/Chl-a ratio) were recorded above all in the PN station.

During the sampling period, the surface temperature reflects the seasonal sampling period and varied from 14.34 to $27.91^{\circ} \mathrm{C}$ (Table 4).

The PCA of the biomarker responses (Figure 9) confirmed the importance of these biomarkers in distinguishing the responses amongst the different sites. Several of the biomarkers showed significant correlations. In all the areas, different stress proteins are activated, showing to be linked to inflammatory lesions (infiltrative and nodular) and pathogens, also linked to organic input and temperature.

\section{DISCUSSION}

A variety of stressors may affect the life of an organism, ranging from pollutants of different nature to climate changes. The stress response is a defense reaction of cells to damage that environmental forces inflict on cells and tissues and that then rebound on the entire individual. Therefore, depending on the intensity and the source of stress, different protection mechanisms and prosurvival strategies are mounted. In monitoring programs, mussels are considered suitable organisms for environmental quality assessment since they are able to provide cellular and physiological responses to different stress condition but giving important information on environmental status (Garmendia et al., 2011).

In this paper, we assessed and discussed the seasonal responses of tissue and molecular biomarkers, also correlated with environmental data in mussels located in different coastal sites of Campania Region (Italy).

Principal component analysis (PCA) was applied, showing the strongest correlation linked to the areas other than to the sampling season. 

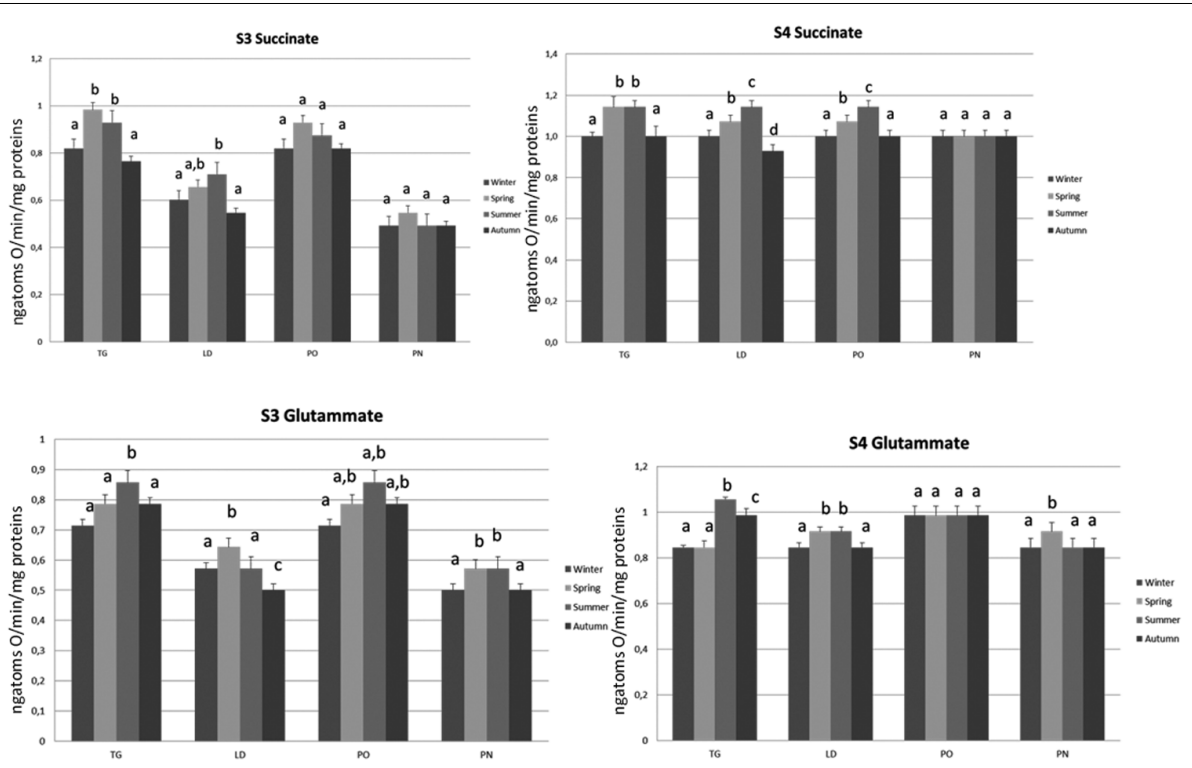

FIGURE 8 | Mitochondrial respiration rates and oxidative stress of $M$. galloprovincialis collected at the different sites and periods. Different superscripted letters indicate statistically significant differences $(P<0.05)$.

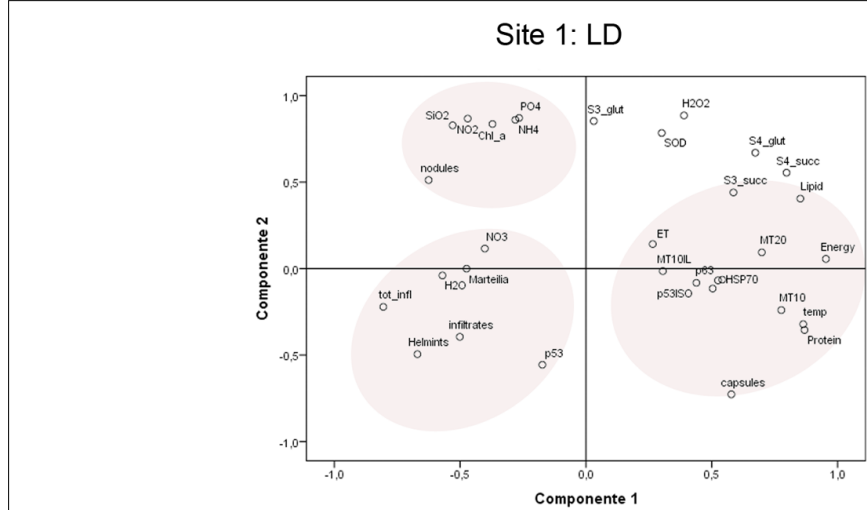

Site 3: PO

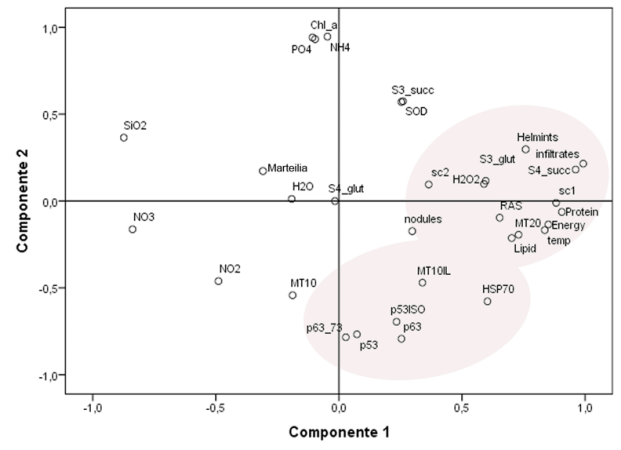

Site 2: PN

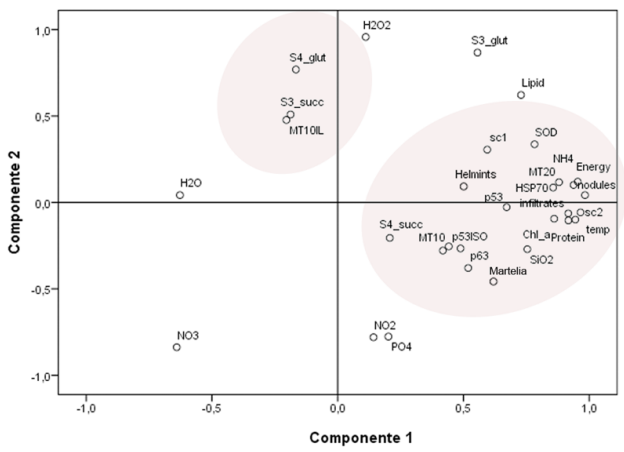

Site 4: TG

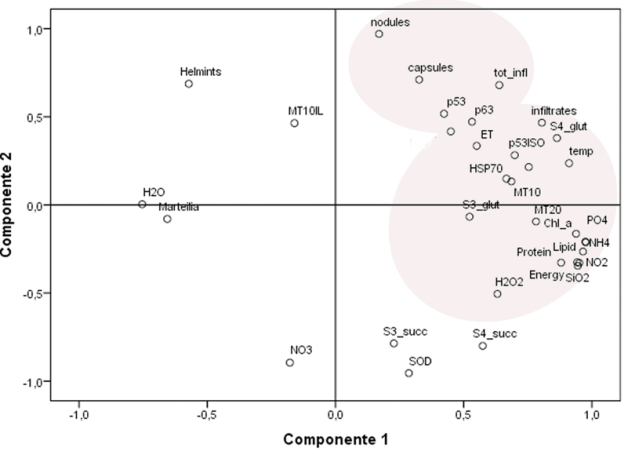

FIGURE 9 | Principal component analysis and site groupings showing the relationship between mussel biomarker responses in the considered areas.

The results of pathological data conducted on samples from the different sites underlined the presence of various pathogenic organisms and lesions of different type. In most of the cases, the prevalence of pathogens and pathologies varied throughout the year with differences only being observed within individual months. Many studies have focused on the digestive tubule epithelial characteristics as target organ for related to chemical exposure. In marine mussels, as in other 
TABLE 3 | Prevalence of the overall Pathogens and Symbionts recorded in M. galloprovincialis samples.

\begin{tabular}{|c|c|c|c|c|c|c|c|}
\hline \multirow{4}{*}{ Sample } & \multirow{4}{*}{$\begin{array}{c}\text { Prokaryote } \\
\text { Nocardia } \\
\text { crassostreae }\end{array}$} & \multicolumn{3}{|c|}{ Protozoa } & \multirow{2}{*}{\multicolumn{2}{|c|}{$\begin{array}{c}\text { Metazoa } \\
\text { Trematodes }\end{array}$}} & \multirow{4}{*}{$\begin{array}{c}\text { Idrozoa } \\
\text { E. inquilina }\end{array}$} \\
\hline & & \multirow{3}{*}{$\begin{array}{c}\text { Cercozoa } \\
\text { M. refringens }\end{array}$} & \multirow{3}{*}{$\begin{array}{l}\text { Microsporidia } \\
\text { S. mytilovum }\end{array}$} & \multirow{3}{*}{$\begin{array}{c}\text { Gill Ciliated } \\
\text { A. mytili }\end{array}$} & & & \\
\hline & & & & & Urostoma sp. & Trematodes & \\
\hline & & & & & \multicolumn{2}{|r|}{$\begin{array}{c}\text { Metacercariae/ } \\
\text { Sporocysts }\end{array}$} & \\
\hline LDa & 0 & 3.3 & 10 & 0 & 0 & 0 & 3.3 \\
\hline LDb & 0 & 0 & 0 & 6.6 & 3.3 & 0 & 0 \\
\hline LDc & 0 & 10 & 10 & 0 & 0 & 10 & 0 \\
\hline LDd & 0 & 10 & 3.3 & 0 & 10 & 6.6 & 13 \\
\hline $\mathrm{POa}$ & 0 & 0 & 6.6 & 13 & 0 & 0 & 0 \\
\hline $\mathrm{POb}$ & 0 & 0 & 10 & 0 & 0 & 0 & 0 \\
\hline POc & 0 & 0 & 0 & 0 & 0 & 13 & 0 \\
\hline POd & 0 & 0 & 0 & 13 & 0 & 0 & 0 \\
\hline $\mathrm{PNa}$ & 6.6 & 3.3 & 10 & 0 & 0 & 6.6 & 6.6 \\
\hline $\mathrm{PNb}$ & 13 & 23 & 6.6 & 0 & 0 & 0 & 0 \\
\hline PNc & 3.3 & 6.6 & 0 & 3.3 & 0 & 6.6 & 0 \\
\hline PNd & 3.3 & 16 & 0 & 6.6 & 0 & 0 & 0 \\
\hline TGa & 0 & 6.6 & 16.6 & 3.3 & 3.3 & 10 & 26.6 \\
\hline TGb & 0 & 33.3 & 0 & 0 & 0 & 16 & 6.6 \\
\hline TGc & 0 & 26.6 & 0 & 3.3 & 0 & 0 & 3.3 \\
\hline TGd & 0 & 0 & 0 & 0 & 0 & 23 & 6.6 \\
\hline
\end{tabular}

TABLE 4 | Environmental data in surface water of each area: inorganic nutrients [DIN ([NO $\left.{ }_{3}^{-}+\mathrm{NO}_{2}{ }^{-}+\mathrm{NH}_{4}+\right), \mathrm{PO}_{4}{ }^{3-}$, Si(OH) 4 ] $(\mu \mathrm{M})$; DIN/P ratio; Chl-a $\left(\mu \mathrm{g} \mathrm{L}{ }^{-1}\right)$ and Phaeo/Chl-a ratio [Phaeopigments/Chl-a]; temperature $\left({ }^{\circ} \mathrm{C}\right)$.

\begin{tabular}{|c|c|c|c|c|c|c|c|}
\hline & & DIN & $\mathrm{PO}_{4}{ }^{3-}$ & $\mathrm{Si}(\mathrm{OH})_{4}$ & Chl-a & Phaeo/Chl-a & Temp \\
\hline & $15 / 05 / 2012$ & 13.773 & 3.839 & 7.806 & 5.914 & 0.48 & 18.13 \\
\hline & $11 / 10 / 2012$ & 0.924 & 0.081 & 1.264 & 1.516 & 0.52 & 22.15 \\
\hline \multirow[t]{3}{*}{$\mathrm{PO}$} & 01/03/2012 & 1.108 & 0.044 & 1.273 & 0.459 & 0.66 & 14.34 \\
\hline & $15 / 05 / 2012$ & 0.894 & 0.116 & 1.322 & 2.191 & 0.33 & 17.92 \\
\hline & $11 / 10 / 2012$ & 0.349 & 0.031 & 1.135 & 0.276 & 0.34 & 22.71 \\
\hline \multirow[t]{4}{*}{ PN } & $12 / 12 / 2011$ & 30.730 & 2.210 & 3.750 & 6.450 & 0.74 & 17.10 \\
\hline & $17 / 05 / 2012$ & 13.561 & 0.635 & 7.894 & 1.757 & 1.20 & 18.38 \\
\hline & 09/07/2012 & 80.889 & 3.881 & 17.206 & 16.030 & 0.52 & 27.88 \\
\hline & $11 / 10 / 2012$ & 41.838 & 10.381 & 18.356 & 6.435 & 1.47 & 23.69 \\
\hline$T G$ & 07/12/2011 & 3.180 & 0.270 & 1.620 & 3.160 & 0.62 & 16.90 \\
\hline
\end{tabular}

bivalve species, the digestive gland is a central organ for animal digestion and homeostasis. Changes in morphology of digestive tubules, along with other histopathological alterations, represent a non-adaptive response to pollutant exposure and stress (Cajaraville et al., 1992; Marigómez et al., 1992, 1996; Carella et al., 2015b). Atrophy and changes in the morphology of the digestive alveoli constitute a non-specific, fast inducible and slowly/not recoverable response to stressful environmental conditions (Brown et al., 1992). Histopathological changes in the digestive structure bring consequently to impairment functions of digestive activity and consequent modification of animal physiology. Previous studies have reported increased atrophic condition of the digestive gland epithelium following both short- and long-term exposure to PAHs or other pollutants. In our study, regressive changes at digestive tissue level were frequently reported. The digestive gland tissue showed the most severe damage in the mussels from LD and PN over the samplings; the most represented lesions were lumen dilation, and tubule necrosis correlated with inflammatory lesions, as also previously reported in the bivalves from heavily 
TABLE 5 | Pearson correlations between gene expression, inflammations, and environmental data.

\begin{tabular}{|c|c|c|c|c|c|c|c|c|c|c|c|}
\hline & p53 & p63 & HSP70 & tot_jnfl & temp & NH4 & N02 & N03 & P04 & Si02 & Chl_a \\
\hline \multirow[t]{2}{*}{ p53 } & 1 & $0.779 * *$ & $0.702^{* *}$ & 0.293 & 0.460 & $0.686^{* *}$ & 0.300 & -0.176 & 0.250 & 0.131 & $0.619^{*}$ \\
\hline & & 0.000 & 0.002 & 0.270 & 0.073 & 0.003 & 0.259 & 0.514 & 0.351 & 0.629 & 0.011 \\
\hline \multirow[t]{2}{*}{ p63 } & $0.779 * *$ & 1 & 0.479 & 0.290 & 0.245 & 0.368 & 0.157 & -0.247 & 0.109 & 0.104 & 0.370 \\
\hline & 0.000 & & 0.060 & 0.276 & 0.360 & 0.160 & 0.562 & 0.356 & 0.688 & 0.701 & 0.158 \\
\hline \multirow[t]{2}{*}{ MDM } & $0.755^{* *}$ & $0.813^{* *}$ & $0.655^{* *}$ & $0.532^{*}$ & $0.503^{*}$ & $0.523^{*}$ & 0.019 & -0.355 & 0.024 & 0.155 & 0.465 \\
\hline & 0.001 & 0.000 & 0.006 & 0.034 & 0.047 & 0.038 & 0.945 & 0.177 & 0.929 & 0.566 & 0.070 \\
\hline \multirow[t]{2}{*}{ HSP70 } & $0.702^{* *}$ & 0.479 & 1 & 0.497 & $0.670^{* *}$ & 0.484 & 0.090 & -0.175 & 0.097 & $0.525^{*}$ & $0.556 *$ \\
\hline & 0.002 & 0.060 & & 0.050 & 0.005 & 0.057 & 0.740 & 0.516 & 0.720 & 0.037 & 0.025 \\
\hline
\end{tabular}

Significantly different values $\left(<0.05^{*},<0.01^{* *}\right)$ are indicated in green.

stressful and polluted sites (Syasina et al., 1997; Usheva et al., 2006).

Depending on the host age and stress conditions, environmental factors such as temperature, oxygen, nutrient presence and other factors can cooperate to activate pathogen virulence in susceptible species, thus triggering parasite/pathogen replication and transmission (Harvell et al., 1999). About the presence of the OIE listed Marteilia sp. pathogen and the microsporidia S. mytilovum, these parasites are considered potentially harmful, but mussel populations of different areas have shown distinct vulnerability related to their genetic origin (Bignell et al., 2008). Although the presence of Marteilia is not always harmful in this specific bivalve species, environmental conditions like high water temperatures for continued periods or low water quality, can weaken the animal, leading to disease or death of the most vulnerable animals (Audemard et al., 2001). Previous works reported the presence of Marteilia refringens in M. galloprovincialis farms in the Gulf of Naples (Carella et al., 2010); however, in the present study the authors detected higher prevalence both in the farm and in the wild population. Recent studies revealed that, at least in Mediterranean waters, where temperatures reach high values, Marteilia parasite has two periods for optimal multiplication and transmission during the year: spring/summer and autumn. This dynamic is correlated with bivalve spawning, zooplankton distribution in the area, also linked to food abundance and temperatures (Boyer et al., 2013). The bacteria belonging to Nocardia sp. normally exist as soil saprophytes, ubiquitous in fresh and salt water, dust, decaying vegetation and fecal deposits from animals. Since the late 1940s, nocardiosis of bivalves has been observed in association with summer mortality in Pacific oysters at several warm locations along the coasts of Japan and subsequently North America (Takeuchi et al., 1955), also reported in the Gulf of Naples in flat oysters and Mediterranean mussels (Carella et al., 2013a). Infection and mortalities seem to be highest for animals lives on a muddy substrate. However, other environmental factors such as reduced water circulation of superficial embayments, warmest temperatures and great nutrient levels can also increase the prevalence of infection of nocardiosis (Bower et al., 2005) as also reported in the PN station as showed by Chl-a values. Interestingly, recent reports assessed for the first time infection of $N$. crassostreae as emerging human pathogen causing invasive pulmonary nocardiosis in immunosuppressed and immunocompetent patients (Taj-Aldeen et al., 2013; Igbaseimokumo et al., 2016). This data suggest $N$. crassostreae to be a possible emerging disease with consequent possible risk of zoonotic infections. The DSD, Disorders of Sex Development, is a condition in which development of chromosomal, gonadal or anatomical sex is atypical and the reproductive organs differ from those classically associated as being male or female (Kim and Kim, 2012). This condition has been reported in humans and in wild animals like bird, fishes and reptiles, and related with specific types of pollutants like endocrine disrupting chemicals (EDC) (Khan and Law, 2005). The EDC interfere with animals hormonal systems, such as androgen and estrogen signaling pathways and resulting in an increased frequency of failure of the reproductive organs bring to lowered fertility (Schug et al., 2011). In estuarine/marine environments, effects on fish reproduction with up-regulation of aromatases and vitellogenins in males and juveniles and the presence of intersex individuals was reported (Ortiz-Zarragoitia et al., 2014). In bivalves, growing evidence supports the hypothesis that a wide range of EDC can affect sex determination, sex ratio, gonadal and gamete development, and larval growth (Nice et al., 2003; Nice, 2005). The mussel M. galloprovincialis is a strictly gonochoristic species (Gosling, 2003). Lately, cases of abnormal hermaphroditism were reported in literature in dioecious species such as Mytilus edulis and M. galloprovincialis (Devauchelle, 1990; Ponurovsky and Yakovlev, 1992) and related to this specific kind of chemicals. In this study, interestingly, mussels of autumn season from LD and TG and in summer from PN showed signs of distressed gamete development, with high prevalence of oocyte atresia linked to high incidence of hermaphroditism/intersex cases.

In mussels, metallothionein belongs to two different gene classes, MT10 and MT20, reported to show different expression at basal conditions and under heavy metal challenge (Aceto et al., 2011). At the same time, heat shock proteins (HSPs) chaperone activity regulates the activity of proteins that are involved in cell cycle machinery like p53, that has an important role in cell cycle control and apoptosis (Zylicz et al., 2001). Under stress condition, like heat shock, inhibitors of energy metabolism, presence of heavy metals, oxidative stress or inflammation, HSP70 increase expression bring to an increased cell survival strategies by protecting and disaggregating stress labile proteins (Skowyra et al., 1990), and with the proteolysis of the damaged proteins (Wickner et al., 1999). In our study, inflammatory 
and DSD lesions form these areas showed a strong correlation with the expression levels of the p53, MT-10, MT-20, HSP70 genes and high inorganic nutrient input. On the other side, presence of infiltrative and nodular inflammations was also linked to $M T$ 10, MT-20 expression levels, but mostly with higher temperature, SOD and $\mathrm{NH}_{4}$. The high level of expression of the p53, MT-10, and HSP70 genes in the mussels collected in the sites examined, in particular PN and TG, suggests that these animals are subjected to a general environmental stress possibly due to the scarce quality of the water for an increase in the supply of organic matter in these sites.

At the same time, the highest values of Chl-a were recorded in the PN and TG stations (16.030 and $10.470 \mathrm{mg} \mathrm{L}^{-1}$, respectively) and reflected the phytoplankton biomass due to effects of anthropogenic nutrient loading. In PN station, the degraded pigments (high values of Pheo/Chl-a ratio) were recorded. The high Pheao/Chl-a ratios suggest the occurrence senescent (instead of grazed) phytoplankton cells (Hendry et al., 1987). This aspect suggests the accumulation of phaeopigments within phytoplankton cells during adverse growth conditions (Hendry et al., 1987) and/or pheopigments packed in fecal pellets with could be rapidly exported from surface waters to the benthic community bottom, (Caron et al., 2004) constituting an important food source for benthic community (Caron et al., 2004). Differently, in the PO station the mean value of Chl-a is $0.765 \mathrm{mg} \mathrm{L}^{-1}$ that fall within the range of those found for the Gulf of Naples and for coastal areas with low nutrient enrichment (Ribera d'Alcalà et al., 2003; Mangoni et al., 2016). The DIN/P ratio shows an altered ratio due to local inputs or to a high uptake of nitrogen by phytoplankton. The DIN/P ratio has exceeded 16 during all seasons in $\mathrm{PN}$, TG stations, thus marking a phosphorous limitation; while in LD station and PO station the DIN/P ratio is much lower to indicate a likely nitrogen-limitation (Ribera d'Alcalà et al., 2003; Pujo-Pay et al., 2011). TG station is densely populated areas, characterized by the presence of many industrial and port activities. During the years, this condition caused widespread contamination of marine sediments, leading to progressive accumulation and pollution of water, air and land (Imperato et al., 2003).

Since the activity of antioxidant enzymes and $\mathrm{H}_{2} \mathrm{O}_{2}$ yield are known to be under extensive seasonal control (Sheehan and Power, 1999), the seasonal pattern of antioxidant defense enzymes found in M. galloprovincialis may be associated to the seasonal variations of temperature and the reproductive cycle. In the mussel Modiolus modiolus it was demonstrated by an increase of the concentration of rate-limiting metabolic enzymes to compensate the reduction of the temperature, while the same level of antioxidant protection were maintained in Summer and Winter (Lesser and Kruse, 2004).

\section{REFERENCES}

Abele, D., Philipp, E., Gonzalez, P., and Puntarulo, S. (2007). Marine invertebrate mitochondria and oxidative stress. Front. Biosci. 12, 933-946. doi: 10.2741/2115
Furthermore, the increase in temperature is followed by an increase in oxygen consumption and by an increase in ROS generation. Also the metabolic particularity of the stages of the reproductive cycle represents a season-related determining factor and influences the levels of antioxidants in the mussels. Therefore, the obtained results and the conclusions of this study reinforce the importance of seasonality on the antioxidant status of Bivalvia in relation to the interpretation of biomonitoring data (Wilhelm-Filho et al., 2001).

\section{CONCLUSION}

Cellular stress response is part of the normal physiology of every animal ensure cell survival.

In this study tissue responses provided insight into the mussel health status of the area. Histopathology has been deeply used in studies of aquatic animal health, coupled with other tools common in different monitoring programs. The integration of multiple histopathological traits along with marker of cellular stress permitted a more sensitive discrimination of different sites and provided a ranking of sites that is in agreement with environmental variables. A series of pathogens and lesions were observed, one of them also of interest also for human health. The most diverse community of parasites and lesions linked to stressors was observed at sites with poor water quality. The major areas of concern, the PN and PO, were observed to be compatible with respect to environmental quality. Further research are in course in our laboratory to clarify possible causes of the observed effects in mussels from Campanian coastline.

\section{AUTHOR CONTRIBUTIONS}

FC: pathological study and organization of the work. SA: gene expression analysis. OM: environmental data analysis. MM: stress response and energy content. GC and GT: stress response and energy content. FA: bioinformatic analysis. GDV: pathological study.

\section{FUNDING}

This work was supported by a grant from the University of Naples Federico II (FARO, 2011).

\section{ACKNOWLEDGMENTS}

The authors thank Dr. Grazia Villari for the technical support.

Aceto, S., Formisano, G., Carella, F., De Vico, G., and Gaudio, L. (2011). The metallothionein genes of Mytilus galloprovincialis: genomic organization, tissue expression and evolution. Mar. Genomics 4, 61-68. doi: 10.1016/j.margen.2011. 01.001 
Albanese, S., De Vivo, B., Lima, A., Cicchella, D., Civitillo, D., and Cosenza, A. (2010). Geochemical baselines and risk assessment of the Bagnoli brownfield site coastal sea sediments (Naples, Italy). J. Geochem. Explor. 105, 19-33. doi: 10.1016/j.gexplo.2010.01.007

Altavista, P., Belli, S., Bianchi, F., Binazzi, A., Comba, P., Del Giudice, R., et al. (2004). Cause-specific mortality in an area of Campania with numerous waste disposal sites. Epidemiol. Prev. 28, 311-321.

Arienzo, M., Donadio, C., Mangoni, O., Bolinesi, F., Stanislao, C., Trifuoggi, M., et al. (2017). Characterization and source apportionment of PAHS in the sediments of the Gulf of Pozzuoli (Campania, Italy). Marine Poll. Bull. 124, 480-487. doi: 10.1016/j.marpolbul.2017.07.006

Audemard, C., Barnaud, A., Collins, C. M., Le Roux, F., Sauriau, P. G., Coustau, C., et al. (2001). Claire ponds as an experimental model for Marteilia refringens life-cycle studies: new perspectives. J. Exp. Mar. Biol. Ecol. 257, 87-108. doi: 10.1016/S0022-0981(00)00330-0

Barja, G. (1998). Mitochondrial free radical production and aging in mammals and birds. Ann. N.Y. Acad. Sci. 854, 224-238. doi: 10.1111/j.1749-6632.1998. tb09905. $\mathrm{x}$

Beaugrand, G., Edwards, M., Raybaud, V., Goberville, E., and Kirby, R. R. (2015). Future vulnerability of marine biodiversity compared with contemporary and past changes. Nat. Clim. Chang. 5, 695-701. doi: 10.1038/nclimate 2650

Bignell, M., Dodge, S., Feist, B., Lyons, P., Martin, N., Taylor, D., et al. (2008). Mussel histopathology: effects of season, disease and species. Aquat. Biol. 2, 1-15. doi: 10.3354/ab00031

Bower, S. M., Goh, B., Meyer, G. R., Carnegie, R. B., and Gee, A. (2005). "Epizootiology and detection of nocardiosis in oysters," in 5th Symp Diseases in Asian Aquaculture, eds P. Walker, R. G. Lester, and M. G. Bondad-Reantaso. (Surfer's Paradise: Fish Health Section, Asian Fisheries Society, Manila), 249-262.

Boyer, S., Chollet, B., Bonnet, D., and Arzul, I. (2013). New evidence for the involvement of Paracartia grani (Copepoda, Calanoida) in the life cycle of Marteilia refringens (Paramyxea). Int. J. Parasitol. 43, 1089-1099. doi: 10.1016/ j.ijpara.2013.07.008

Brown, R. P., Cristini, A., and Cooper, K. R. (1992). Histopathological alterations in Mya arenaria following a \#2 fuel oil spill in the Arthur Kill, Elizabeth, New Jersey. Mar. Environ. Res. 34, 65-68. doi: 10.1016/0141-1136(92) 90084-Y

Cajaraville, M. P., Marigómez, I., Díez, G., and Angulo, E. (1992). Comparative effects of the water accommodated fraction of three oils on mussels. 2 . Quantitative alterations in the structure of the digestive tubules. Comp. Biochem. Physiol. 102C, 113-123.

Carella, F., Aceto, S., Marrone, R., Maiolino, P., and De Vico, G. (2010). Marteilia refringens infection in cultured and natural beds of mussels (Mytilus galloprovincialis) along the Campanian coast (Tirrenian sea, South of Italy). EAFP Bull. 30, 189-196.

Carella, F., Carrasco, N., Andree, K. B., Lacuesta, B., Furones, D., and De Vico, G. (2013a). Nocardiosis in Mediterranean bivalves: first detection of Nocardia crassostreae in a new host Mytilus galloprovincialis and in Ostrea edulis from the Gulf of Naples (Italy). J. Invert. Pathol. 114, 324-328. doi: 10.1016/j.jip.2013.10. 001

Carella, F., Aceto, S., Fiengo, M., Salemme, M., Aniello, F., and De Vico, G. (2013b). Correlation between the expression level of the mdm homolog gene and inflammatory lesions in different populations of the model organism Mytilus galloprovincialis from polluted areas of the Gulf of Naples (southern Italy). Eur. J. Inflamm. 11, 837-846. doi: 10.1177/1721727X13011 00326

Carella, F., Feist, S. W., Bignell, J. P., and De Vico, G. (2015a). Comparative pathology in bivalves: Aetiological agents and disease processes. J. Invert. Pathol. 131, 107-120. doi: 10.1016/j.jip.2015.07.012

Carella, F., Sardo, A., Mangoni, O., Di Cioccio, D., Urciuolo, G., De Vico, G., et al. (2015b). Quantitative histopathology of the Mediterranean mussel (Mytilus galloprovincialis L.) exposed to the harmful dinoflagellate Ostreopsis cf. ovata. J. Invert. Pathol. 127, 130-140. doi: 10.1016/j.jip.2015. 03.001

Caron, G., Michel, C., and Gosselin, M. (2004). Seasonal contributions of phytoplankton and fecal pellets to the organic carbon sinking flux in the North
Water (northern Baffin Bay). Mar. Ecol. Prog. Ser. 283, 1-13. doi: 10.3354/ meps 283001

Chance, B., and Williams, G. R. (1955). Respiratory enzymes in oxidative phosphorylation. III. The steady state. J. Biol. Chem. 217, 409-427.

Cravo, A., Lopes, B., Serafim, A., Company, R., Barreira, L., Gomes, T., et al. (2009). A multibiomarker approach in Mytilus galloprovincialis to assessenvironmental quality. J. Environ. Monit. 11, 1673-1686. doi: 10.1039/B90 9846A

de Sherbinin, A., Carr, D., Cassels, S., and Jiang, L. (2007). Population and Environment. Annu. Rev. Environ. Resour. 32, 345-373. doi: 10.1146/annurev. energy.32.041306.100243

De Vico, G., and Carella, F. (2012). Morphological features of the inflammatory response in molluscs. Res. Vet. Sci. 93, 1109-1115. doi: 10.1016/j.rvsc.2012. 03.014

Devauchelle, N. (1990). "Sexual development and maturity of Tapes philippinarum," in Tapes philippinarum, Biologia e sperimentazione, Vol. 3, (Verone: Ente Sviluppo Agricolo), 47-62.

Estabrook, R. W. (1967). Mitochondrial respiratory control and the polarographic measurement of ADP:O ratios. Methods Enzymol. 10, 41-47. doi: 10.1016/00766879(67)10010-4

FAO (2015). Available at: http://www.fao.org/fishery/countrysector/naso_italy/es

Flohé, L., and Otting, F. (1984). Superoxide dismutase assays. Methods Enzymol. 105, 93-104. doi: 10.1016/S0076-6879(84)05013-8

Folch, J., Lees, M., and Sloane Stanley, G. H. S. (1957). A simple method for the isolation and purification of total lipides from animal tissues. J. Biol. Chem. 226, 497-509.

Gagné, F., Gagnon, C., Turcotte, P., and Blaise, C. (2007). Changes in metallothionein levels in freshwater mussels exposed to urban wastewaters: effects from exposure to heavy metals? Biomark. Insights. 2, 107-116. doi: 10. $1177 / 117727190700200012$

Garmendia, L., Soto, M., Vicario, U., Kim, Y., Cajaraville, M. P., and Marigómez, I. (2011). Application of a battery of biomarkers in mussel digestive gland to assess long-term effects of the Prestige oil spill in Galicia and Bay of Biscay: tissue-level biomarkers and histopathology. J. Environ. Monit. 13, 915-932. doi: $10.1039 / \mathrm{c} 0 \mathrm{em} 00410 \mathrm{c}$

Gosling, E. (2003). Bivalve Molluscs: Biology, Ecology and Culture (Oxford: Blackwell Publishing Ltd.) 1-24.

Gutiérrez, M. (1977). Nota sobre marteliasis del mejillón, Mytilus edulis de la costa noroeste española. Inv. Pesq. 41, 637-644.

Hansen, H. P., and Grasshoff, K. (1983). "Automated chemical analysis," in Methods of Seawate r Analysis, 2nd Edn, eds K. Grasshoff, M. Ehrhardt, and K. Kremlin (Weinheim: Verlag Chemie), 347-379.

Hartree, E. E. (1972). Determination of protein. A modification of the Lowry method that gives a linear photometric response. Anal. Biochem. 48, 422-427. doi: 10.1016/0003-2697(72)90094-2

Harvell, C. D., Kim, K., Burkholder, J. M., Colwell, R. R., Epstein, P. R., and Grimes, D. J. (1999). Emerging marine diseases: climate links and anthropogenic factors. Science 285, 1505-1510. doi: 10.1126/science.285.5433. 1505

Hendry, G. A. F., Houghton, J. D., and Brown, S. B. (1987). The degradation of chlorophyll - a biological enigma. New Phytol. 107, 255-302. doi: 10.1111/j. 1469-8137.1987.tb00181.x

Hook, S. E., Evan, P., Gallagher, E. P., and Batley, G. E. (2014). The role of biomarkers in the assessment of aquatic ecosystem health. Integr. Environ. Assess. Manag. 10, 327-341. doi: 10.1002/ieam.1530

Howard, D. W., and Smith, C. S. (1983). "Histological Techniques for Marine Bivalve Mollusks," in NOAA Technical Memorandum NMFS-F/NEC-25, (Woods Hole, MA: National Oceanic and Atmospheric Administration).

Igbaseimokumo, U., El Shafie, S., and Al Khal, A. L. (2016). First human infection of Nocardia crassostreae in an immunocompetent patient. Chinese Med. J. (Engl). 129, 114-115. doi: 10.4103/0366-6999.17 2609

Imperato, M., Adamo, P., Naimo, D., Arienzo, M., Stanzione, D., and Violante, P. (2003). Spatial distribution of heavy metals in urban soils of Naples city (Italy). Environ. Pollut. 124, 247-256. doi: 10.1016/S0269-7491(02)00 $478-5$ 
Iossa, S., Mollica, M. P., Lionetti, L., Crescenzo, R., Botta, M., and Liverini, G. (2002). Skeletal muscle oxidative capacity in rats fed high-fat diet. Int. J. Obes. 26, 65-72. doi: 10.1038/sj.ijo.0801844

Iterar, C., Orabona, F., Raddi, C., and Scalera, B. (2012). Territorial vulnerability and resilience: the case of Castelvolturno. BDC, 12: 1/2012.

Jeffrey, S. W., and Humphrey, G. F. (1975). New spectrophotometric equations for determining chlorophylls $\mathrm{a}, \mathrm{b}, \mathrm{cl}$ and $\mathrm{c} 2$ in higher plants, algae and natural phytoplankton. Bioch. Physiol. Pflanzen. 167, 191-194. doi: 10.1016/S00153796(17)30778-3

Khan, M. Z., and Law, F. C. P. (2005). Adverse effects of pesticides and related chemicals on enzyme and hormone systems of fish, amphibians and reptiles: a review. Proc. Pak. Acad. Sci. 42, 315-323.

Kim, K. S., and Kim, J. (2012). Disorders of sex development. Korean J. Urol. 53, 1-8. doi: 10.4111/kju.2012.53.1.1

Kim, Y., Ashton-Alcox, A., and Powell, E. N. (2006). Histological techniques for marine bivalve molluscs: update NOAA technical memorandum NOS NCCOS 27, 76 pp Status and Trends 'Mussel Watch'. Program. Mar. Environ. Res. 65, 101-127. doi: 10.1016/j.marenvres.2007.09.003

Knapen, D., Reynders, H., Bervoets, L., Verheyen, E., and Blust, R. (2007). Metallothionein gene and protein expression as a biomarker for metal pollution in natural gudgeon populations. Aquat. Toxicol. 82, 163-172. doi: 10.1016/j. aquatox.2007.02.008

Lauenstein, G. (2012). NOAA Flexes Mussels for Tracking Pollution. Available at: https://usresponserestoration.wordpress.com/2012/01/11/noaa-musselwatch-program

Lehtonen, K. K., Sundelin, B., Lang, T., and Strand, J. (2014). Development of tools for integrated monitoring and assessment of hazardous substances and their biological effects in the Baltic Sea. AMBIO 43, 69-81. doi: 10.1007/s13280-0130478-3

Lesser, M. P., and Kruse, V. A. (2004). Seasonal temperature compensation in the horse mussel, Modiolus modiolus: metabolic enzymes, oxidative stress and heat shock proteins. Comp. Biochem. Physiol. A. Mol. Integr. Physiol. 137, 495-504. doi: 10.1016/j.cbpb.2003.10.022

Mangoni, O., Aiello, G., Balbi, S., Barra, D., Bolinesi, F., Donadio, C., et al. (2016). A multidisciplinary approach for the characterization of the coastal marine ecosystems of Monte Di Procida (Campania. Italy). Marine Poll. Bull. 112, 443-451. doi: 10.1016/j.marpolbul.2016.07.008

Marigómez, I., Orbea, A., Olabarrieta, I., Etxeberria, M., and Cajaraville, M. P. (1996). Structural changes in the digestive lysosomal system of sentinel mussels as biomarkers of environmental stress in mussel-watch programmes. Comp. Biochem. Physiol. 113, 291-297. doi: 10.1016/0742-8413(95) 02100-0

Marigómez, I., Soto, M., and Angulo, E. (1992). Seasonal variability in the quantitative structure of the digestive tubules of Littorina littorea. Aquat. Living. Resour. 5, 299-305. doi: 10.1051/alr:1992028

Marigomez, I., Zorita, I., Izagirre, U., Ortiz-Zarragoitia, M., Navarro, P., Etxebarria, N., et al. (2013). Combined use of native and caged mussels to assess biological effects of pollution through the integrative biomarker approach. Aquat. Toxic. 13, 32-48. doi: 10.1016/j.aquatox.2013.03.008

Mazzi, V. (1977). Manuale di tecniche istologiche e istochimiche. Rome: Piccin.

Nice, H. E. (2005). Sperm motility in the Pacific oyster (Crassostrea gigas) is affected by nonyphenol. Mar. Pollut. Bull. 50, 1668-1674. doi: 10.1016/j.marpolbul. 2005.07.006

Nice, H. E., Morritt, D., Crane, M., and Thorndyke, M. (2003). Long term and transgenerational effects of nonylphenol exposure at a key stage in the development of Crassostrea gigas. Possible endocrine disruption? Mar. Ecol. Prog. Ser. 256, 293-300. doi: 10.3354/meps256293

Ortiz-Zarragoitia, M., Bizarro, C., Rojo-Bartolomé, I., Diaz de Cerio, O., Cajaraville, M. P., and Cancio, I. (2014). Mugilid fish are sentinels of exposure to endocrine disrupting compounds in coastal and estuarine environments. Mar. Drugs 12, 4756-4782. doi: 10.3390/md12094756

Pagliarani, V., Ventrella, F., Trombetti, M., Pirini, G., Trigari, A. R., and Borgatti. (1994). Andamento stagionale dell?attività di complessi della catena respiratoria mitocondriale di alcuni tessuti di Mytilus galloprovincialis Lam Biol. Mar. Medit. 1, 383-384.

Ponurovsky, S. K., and Yakovlev, Y. M. (1992). The reproductive biology of the Japanese littleneck, Tapes philippinarum (A. Adams and Reeve. 1850)
(Bivalvia: Veneridae). J. Shell. Res. 11, 265-277. doi: 10.1017/S002531541700 1382

Pugnetti, A., Camatti, E., Mangoni, O., Morabito, G., Oggioni, A., and Saggiomo, V. (2006). The phytoplankton production in Italian freshwater and marine ecosystems: state of the art and perspectives. Chem. Ecol. 22(Suppl. 1), S49-S69. doi: 10.1080/02757540600557330

Pujo-Pay, M., Conan, P., Oriol, L., Cornet-Barthaux, V., Falco, C., Ghiglione, J. F., et al. (2011). Integrated survey of elemental stoichiometry (C, N, P) from the western to eastern Mediterranean Sea. Biogeosciences 8, 883-899. doi: 10.5194/ bg-8-883-2011

Ramiìrez, F., Afán, I., Davis, L. S., and Chiaradia, A. (2017). Climate impacts on global hot spots of marine biodiversity. Sci. Adv. 3:e1601198. doi: 10.1126/ sciadv. 1601198

Ribera d'Alcalà, M., Civitarese, G., Conversano, F., and Lavezza, R. (2003). Nutrient ratios and fluxes hint at overlooked processes in the Mediterranean Sea. J. Geophys. Res. 108:8106. doi: 10.1029/2002jc001650

Ribera d'Alcalà, M., Conversano, F., Corato, F., Licandro, P., Mangoni, O., Marino, D., et al. (2004). Seasonal patterns in plankton communities in a pluriannual time series at a coastal Mediterranean site (Gulf of Naples): an attempt to discern recurrences and trends. Sci. Mar. 68(Suppl. 1), 65-83. doi: 10.3989/scimar.2004.68s 165

Salihoglu, B., Neuer, S., Painting, S., Murtugudde, R., Hofmann, E. E., Steele, J. H., et al. (2013). Bridging marine ecosystem and biogeochemistry research: lessons and recommendations from comparative studies. J. Mar. Syst. 109-110, 161-175. doi: 10.3989/scimar.2004.68s 165

Schug, T. T., Janesick, A., Blumberg, B., and Heindel, J. J. (2011). Endocrine disrupting chemicals and disease susceptibility. J. Ster. Biochem. Molec Biol. 127, 204-215. doi: 10.1016/j.jsbmb.2011.08.007

Sheehan, D., and Power, A. (1999). Effects of seasonality on xenobiotic and antioxidant defence mechanism of bivalve molluscs. Comp. Biochem. Physiol. C 123, 193-199. doi: 10.1016/S0742-8413(99)0 0033-X

Skowyra, D., Georgopoulos, C., and Zylicz, M. (1990). The E. coli dnaK gene product, the hsp70 homolog, can reactivate heat-inactivated RNA polymerase in an ATP hydrolysis-dependent manner. Cell 62, 939-944. doi: 10.1016/00928674(90)90268-J

Sprovieri, M., Feo, M. L., Prevedello, L., Manta, D. S., Sammartino, S., Tamburrino, S., et al. (2007). Heavy metals, polycyclic aromatic hydrocarbons and polychlorinated biphenyls in surface sediments of the Naples harbour (southern Italy). Chemosphere 67, 998-1009. doi: 10.1016/j.chemosphere.2006. 10.055

Syasina, I. G., Vaschenko, M. A., and Zhandan, P. M. (1997). Morphological alterations in the digestive diverticula of Mizuhopecten yessoensis (Bivalvia: Pectenidae) from polluted areas of Peter the Great Bay. Mar. Environ. Res. 44, 85-98. doi: 10.1016/S0141-1136(96)00 104-3

Taj-Aldeen, S. J., Deshmukh, A., Doiphode, S., Wahab, A. A., Allangawi, M., Almuzrkchi, A., et al. (2013). Molecular identification and susceptibility pattern of clinical Nocardia species: Emergence of Nocardia crassostreae as an agent of invasive nocardiosis. Can. J. Infect. Dis. Med. Microbiol. 24, e33-e38.

Takeuchi, T., Matsubara, T., Hirokawa, H., and Tsukiyama, A. (1955). Bacteriological studies on the unusually high mortality of Ostrea gigas in Hiroshima Bay-I. Bull. Japan. Soc. Fish. Sci. 20, 1066-1070. doi: 10.2331/suisan. 20.1066

Trifuoggi, M., Donadio, C., Mangoni, O., Ferrara, L., Bolinesi, F., Stanislao, C., et al. (2017). Distribution and enrichment of trace metals in surface marine sediments in the Gulf of Pozzuoli and off the coast of the brownfield metallurgical site of Ilva of Bagnoli (Campania. Italy). Mar Poll. Bull. 124, 502-511. doi: 10.1016/j.marpolbul.2017. 07.033

Trinchella, F., Esposito, M., Simoniello, P., and Scudiero, R. (2013). Cadmium, lead and metallothionein contents in cultivated mussels (Mytilus galloprovincialis) from the Gulf of Naples (Southern Italy). Aquaculture Res. 44, 1076-1084. doi: 10.1111/j.1365-2109.2012.03111.x

Usheva, L. N., Vaschenko, M. A., and Durkina, V. B. (2006). Histopathology of the digestive gland of the bivalve mollusc Crenomytilus grayanus (Dunker, 1853) 
from Southwestern Peter the Great Bay, Sea of Japan. Russ. J. Mar. Biol. 32, 166-172. doi: 10.1134/S1063074006030047

Wickner, S., Maurizi, M. R., and Gottesman, S. (1999). Posttranslational quality control: folding, refolding, and degrading proteins. Science 286, 1888-1893. doi: $10.1126 /$ science.286.5446.1888

Wilhelm-Filho, D., Tribessa, T., Gáspari, C., Claudio, F. D., Torres, M. A., and Magalhãesb, A. R. M. (2001). Seasonal changes in antioxidant defenses of the digestive gland of the brown mussel (Perna perna). Aquaculture 203, 149-158. doi: 10.1016/S0044-8486(01)00599-3

Zylicz, M., King, F. W., and Wawrzynow, A. (2001). Hsp70 interactions with the p53 tumour suppressor protein. EMBO J. 20, 4634-4638. doi: 10.1093/emboj/ 20.17.4634
Conflict of Interest Statement: The authors declare that the research was conducted in the absence of any commercial or financial relationships that could be construed as a potential conflict of interest.

Copyright ( 2018 Carella, Aceto, Mangoni, Mollica, Cavaliere, Trinchese, Aniello and De Vico. This is an open-access article distributed under the terms of the Creative Commons Attribution License (CC BY). The use, distribution or reproduction in other forums is permitted, provided the original author(s) and the copyright owner are credited and that the original publication in this journal is cited, in accordance with accepted academic practice. No use, distribution or reproduction is permitted which does not comply with these terms. 